\title{
Integrated Approach to Pore Pressure and Fracture Pressure Prediction Using Well Logs: Case Study of Onshore Niger-Delta Sedimentary Basin
}

\author{
Cyril Ngozi Nwankwo*, Stephen Onoh Kalu \\ Department of Physics, University of Port Harcourt, Port Harcourt, Nigeria \\ Email:*cyrilnn@yahoo.com
}

How to cite this paper: Nwankwo, C.N. and Kalu, S.O. (2016) Integrated Approach to Pore Pressure and Fracture Pressure Prediction Using Well Logs: Case Study of Onshore Niger-Delta Sedimentary Basin. Open Journal of Geology, 6, 1279-1295. http://dx.doi.org/10.4236/ojg.2016.610094

Received: February 16, 2016

Accepted: October 25, 2016

Published: October 28, 2016

Copyright $\odot 2016$ by authors and Scientific Research Publishing Inc. This work is licensed under the Creative Commons Attribution International License (CC BY 4.0).

http://creativecommons.org/licenses/by/4.0/ (c) (i) Open Access

\begin{abstract}
This study investigated the cause of identified zones of overpressure in some selected wells in a field in the Niger Delta sedimentary basin. Two models were used each for predicting pore pressure and the corresponding fracture pressure using well log and drilling data. Shale lithology in Niger Delta is massive and characterized by high pore pressure; hence shale compaction theory is utilized in this study. The petrophysical data were evaluated using Ikon's Science Rokdoc software. The two major pore pressure prediction techniques employed are the Eaton's and Bowers' models while the Eaton's fracture pressure model and the Hubbert and Willis fracture pressure prediction models were utilized for fracture prediction. The density and sonic logs were used respectively to generate the shale trend and the shale normal compaction trend used for the prediction. The wells studied showed disequilibrium compaction of sediment to be the major mechanism that gave rise to overpressure in the Niger Delta. Clay diagenesis and fluid expansion were also observed as the secondary overpressure generation mechanism in well X-1. This secondary overpressure mechanism was observed to start approximately at depths of $10,000 \mathrm{ft}$ (TVD). The top of overpressure and the pressure range in the wells studied varied from 6000 to $11,017 \mathrm{ft}$ (TVD) and 1796.70 to 5297.00 psi respectively. The Eaton's model under-predicts pore pressure at the depth interval where unloading mechanism is witnessed. Since the study revealed presence of secondary overpressure generation mechanism, Bowers model was observed to be the most reliable pore pressure prediction model in the area.
\end{abstract}

\section{Keywords}

Pore Pressure, Fracture Gradient, Overpressure, Models, Niger Delta 


\section{Introduction}

One of the requirements to safe drilling is the knowledge of the formation pore pressure gradient and the corresponding fracture gradient. Pore pressure is the pressure of fluid within the pore spaces of reservoir rock matrix. It is a function of the formation effective stress and overburden stress (the pressure which results from the combined weight of the rock matrix and the fluids in the pore space overlying the formation of interest). When the pore pressure of a formation at any depth is above the hydrostatic pressure for such formation, the pressure is considered to be over-pressured. On the other hand when the formation pressure is below the hydrostatic pressure at any depth, the formation is said to be under-pressured. For normal geologic setting, the normal pressure is the hydrostatic pressure, or the pressure exerted by a column of water from the formation depth to sea level. When impermeable rocks such as shale sediments are compacted, their pore fluids cannot always escape and must then support the total overlying rock column leading to anomalous formation pressure [1].

It is imperative for safety to consider the formation pressure before the drilling operations commence. It is observed that most well kicks encountered during drilling are due to high pressure. The knowledge of the formation pressure gives the drilling engineers clue on the right drilling mud weight to use, casing design and provides proper logistics for the drilling operation [2] [3].

Deep water areas are usually associated with high pore pressure, and owing to energy need of the world and economic viability of such areas, drilling in such areas cannot be overlooked rather. Geoscientists try to develop skill and models to overcome such challenging zones.

According to [4], there are many difficulties in predicting in situ pore pressure from subsurface measurements. This is because one can never remotely measure pore pressure itself but must always measure some other parameters like the seismic velocity and the wave travel time. These quantities are sensitive to porosity, mineralogy and formation pressure and can be used to infer pore pressure indirectly. Owing to these difficulties, the problem of pore pressure prediction can be said to suffer the non-uniqueness problem.

Agbada Formation in the Niger Delta usually has very difficult deep geological structure and multivariate underground pressure system, so it is very significant to efficiently predict its pore pressure in the process of exploration and development of the deep reservoirs in the area [4]. It is very important to consider all the causes of the overpressure so as to develop appropriate model for the drilling operations.

There are many ways to determine pore pressure using drilling data, wire line logs and seismic data. Each method is suitable for different geologic settings and causes of overpressure. This study focuses on comparing wire line log data with that of Wire line Formation Tester (WFT) in predicting the pore pressure in some selected wells in the Niger Delta oil field. Other petrophysical and geologic data were used as guide.

[5] suggested that the causes of overpressure in a formation are disequilibrium compaction of sediment, clay diagenesis, differential density and fluid expansion/fluid mi- 
gration. A robust approach of estimating the cause of overpressure is to use velocity versus density cross-plot in conjunction with knowledge of overpressure mechanisms, rock properties and understanding of basin history [3]. The various signatures of these cross plots are illustrated in Figure 1.

\section{Geologic Setting of Niger Delta}

The Niger Delta is a thick accumulation of tertiary deltaic sediments bordering the Atlantic Ocean and extends from longitude $3^{\circ} \mathrm{E}-9^{\circ} \mathrm{E}$ and latitude $4^{\circ} 30^{\prime} \mathrm{N}-5^{\circ} 20^{\prime} \mathrm{N}$. It is comprised of nine states of the Southern Nigeria (Figure 2). The proto delta developed in the northern part of the basin during the Campanian transgression and ended with the Paleocene transgression [7]. The modern delta started forming during the Eocene

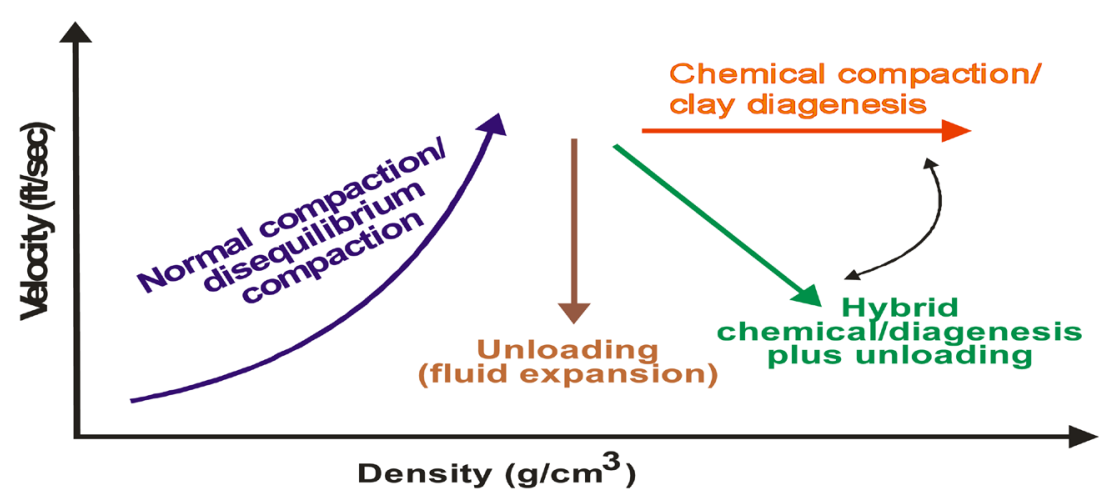

Figure 1. Typical velocity vs. density signatures and their associated, causal mechanisms of overpressure generation [6].

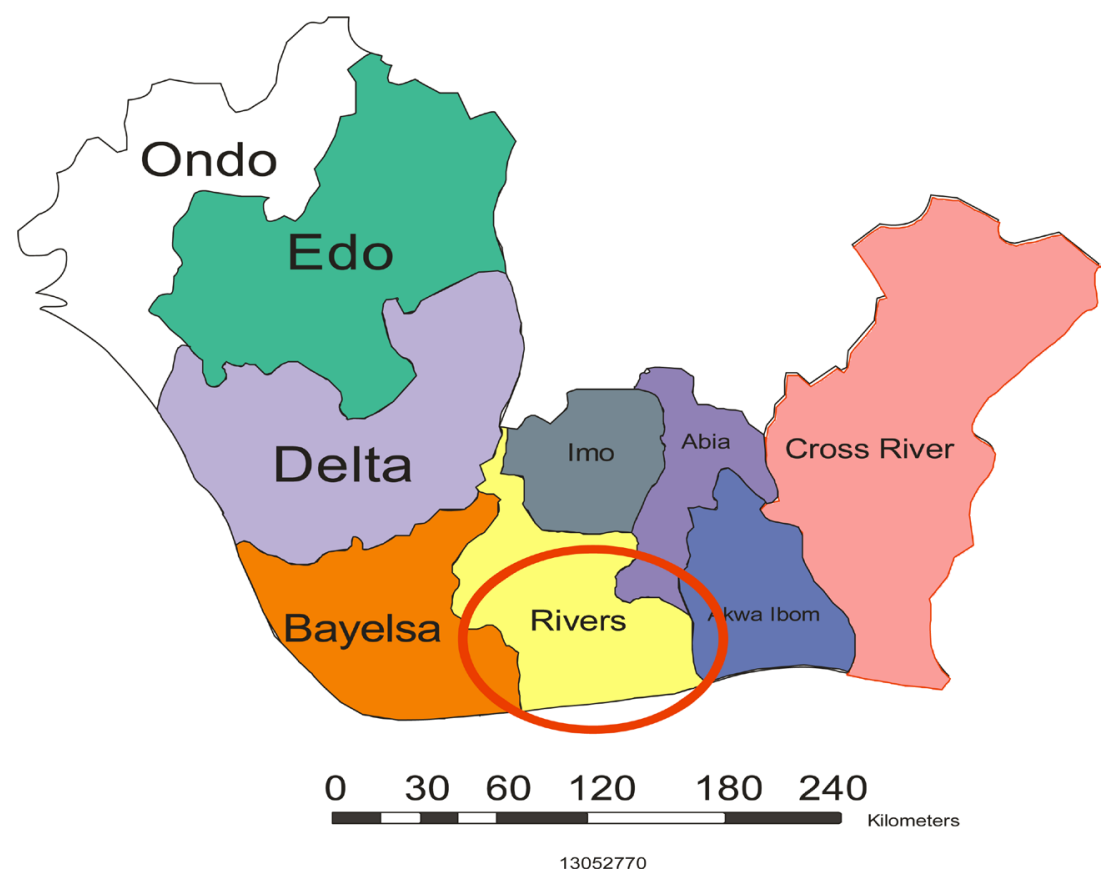

Figure 2. Maps showing the location of the study area (modified from world atlas, Microsoft Encarta 2009 [DVD]; www.gisdevelopment.net). 
period. The Niger Delta has three major depositional environments typical of deltaic environment. These are the Benin, Agbada and Akata Formations.

The Benin Formation is continental deposits of alluvial and upper coastal plain sands. It consists predominantly of fresh water bearing massive continental sand and gravels deposited in an upper deltaic plain environment [8]. Benin Formation extends from the west across the whole Niger Delta area and southward beyond the coastline. It is $90 \%$ sandstone with shale intercalations. The thickness is variable but generally exceeds $6000 \mathrm{ft}$ [7]. Very little hydrocarbon accumulation has been associated with the formation.

Underlie the Benin Formation is the Agbada Formation. Agbada Formation is a sequence of fluviomarine sands, siltstones and shales. It consists of an upper predominantly sandy unit with minor shale intercalation and a lower shale unit which is thicker than the upper sandy unit. According to Kogbe, the Agbada Formation is rich in microfauna at the base decreasing upward and thus indicating an increase in the rate of deposition. It is over $10,000 \mathrm{ft}$ thick and ranges from Eocene in the north to Pliocene/Pleistocene in the south and recent in the delta surface.

The Akata Formation is the lowermost depositional layer and underlies the Agbada Formation. It is of marine origin and it is a uniform shale development consisting of dark grey sandy silt shale with plant remains at the top. It is approximately over $4000 \mathrm{ft}$ thick. Akata Formation is the major source rock in the Niger Delta. The interbeded shale within the Agbada Formation provides the primary seal rock in the Niger Delta.

Majority of the traps in the Niger Delta are structural. These structural traps are formed during sedimentary deformation of the Agbada paralic sequence [9]. Stratigraphic traps are not uncommon on the flanks of the delta.

\section{Materials and Methods}

This study was carried out using six onshore well data from Niger-Delta basin. The data used include Well logs (in ASCII format), deviation survey data (in XLS format), measured pressure data (in Psi) and End of well reports (XLS Format). Because of the existing Laws within the Oil Companies in Nigeria, the exact location of the wells could not be disclosed.

The well logs data used include Gamma Ray, P-Sonic, S-Sonic, Density and Caliper. Some of the wells lack complete set of data listed above. The wells were selected based on availability of its pressure data, End of well reports and the quality of the wire line logs. The quality check on the logs was based on accuracy of their heading, depth discrepancies, gaps and spikes. The data analysis tools used in this study are Ikon Science's Rokdoc for log conditioning, overburden profile generation, estimation of shale volume, normal compaction trends and pore pressure estimation; De Spike Kostia for log despiking and Microsoft Office Excel 2007 for cross-plots of some well logs parameters.

The processing sequences of operation carried out in the study include:

1) Acquisition, identification and review of well data, drilling records, petrophysical data and pressure data. 
2) Analysis of cross-plots to determine the major cause of over-pressure.

3) Application of pore pressure models using the petrophysical and well data.

4) Analysis of the pore pressure models used against the pressure data.

5) Identification of the best model with respect to the well data.

6) Application of fracture gradient model using the pore pressure values from the best fit model.

\subsection{Lithology Discrimination and Volume of Shale Generation}

Gamma Ray log was used to discriminate between sand and shale lithologies. The volume fraction of shale was generated using Ikon Rokdoc software, and the standard equation is

$$
V_{s h}=\left(G R_{\log }-G R_{s d}\right)\left(G R_{s h}-G R_{s d}\right)
$$

where $G R_{\log }$ is the log response, $G R_{s h}$ is the log value in clean shale, and $G R_{s d}$ is the log value in clean sand. Care was taken to select upper and lower limit of the clean shale. Constant density of clay and shale was chosen as $2.680 \mathrm{~g} / \mathrm{cm}^{3}$ based on average mineral grain density.

\subsection{Overburden Stress}

This is an important parameter in pore pressure estimation, as every model considers the weight of the rock matrix and the fluid. The overburden profile was generated from the density log using cumulative summation of the sediment weight for each depth interval at constant sea water density of $1.025 \mathrm{~g} / \mathrm{cm}^{3}$. This estimate was also used to determine the overburden gradient (lithostatic gradient) using Equation (2) (Rokdoc training manual).

$$
\text { Rho }(Z m l)=\text { RhoMatrix }-(\text { RhoMatrix }- \text { RhoTop }) * \exp (-b * Z m l)
$$

where $R h o(Z m l)$ is overburden at depth below mudline, $b$ is compaction coefficient ( $1 / \mathrm{ft}), Z \mathrm{ml}$ is depth below mudline.

When the pore pressure becomes equal to or greater than the overburden (OVB), that is, when the weight of the overburden is supported by pore fluid, the rock will fracture and the fractures will be approximately horizontal [10].

\subsection{Hydrostatic Pressure $\left(P_{h y d}\right)$}

Water density value of $0.433 \mathrm{psi} / \mathrm{ft}(1.025 \mathrm{~g} / \mathrm{cc})$ was used as the average formation water density which is also the hydrostatic pressure gradient. The hydrostatic pressure was then found by multiplying the pressure gradient by the respective depth below mudline. That is

$$
P_{\text {hyd }}=0.433 \times T V D_{\text {BML }}
$$

\subsection{Normal Compaction Trend (NCT)}

The normal compaction trend in this study was picked from $V_{p}$ and Rho. The data quality poses great challenge in picking the normal compaction trend. The lithology 
constitutes majorly of sand at shallow depth while shale interval showed up at greater depth. The normal compaction trend is initially estimated using the reciprocal input log transform given in Equation (4) (Rockdoc, 2014):

$$
\frac{1}{V_{p}(\mathrm{zml})}=\frac{1}{V_{p} \text { matrix }}-\left(\frac{1}{V_{p} \text { matrix }}-\frac{1}{V_{p} \text { top }}\right) * e^{-b * z m l}
$$

where $V_{p}$ top is the compressional wave velocity at or near the surface for onshore data (in $\mathrm{ft} / \mathrm{s}), V_{p}$ matrix is the compressional wave velocity at maximum extrapolated point along depth (in $\mathrm{ft} / \mathrm{s}$ ), $b$ is the compaction coefficient $\left(\mathrm{ft}^{-1}\right)$. The NCT was iteratively tried until a reasonable trend was picked in relation to the cleanest shale interval.

\subsection{Pore Pressure Prediction Models}

This study considers two pore pressure approaches using $V_{p}$ and Rho. The choice of well logs used was based on the availability and quality of data. Resistivity log is mostly affected by several factors like the salinity of the formation fluid, hence it is not considered in this study. The approaches considered are

\section{1) Bowers Model}

The relationship between the effective stress and formation velocity in normal pressure sediment according to [11], is given as

$$
V=V_{0}+A \sigma_{e}^{b}
$$

where

$$
\sigma_{e}=\left[\frac{V-V_{0}}{A}\right]^{1 / b}
$$

$V$ is the acoustic velocity, $\sigma_{e}$ is the effective stress, $V_{0}$ is the velocity of unconsolidated fluid saturated sediments. $A$ and $b$ are constants which describe the variation in velocity with increasing differential stress.

But the vertical effective stress

$$
\sigma_{e}=S-P
$$

where $S=$ overburden stress, $P=$ pore pressure.

Therefore Equation (6) can be modified as

$$
P_{p}=S-\sigma_{e}=S-\left[\frac{V-V_{0}}{A}\right]^{1 / b}
$$

Prediction can be made with either $V_{p}$ or Rho (Ikon's Science training manual) using:

$$
\left.\begin{array}{l}
V p ; P_{p}=S-\sigma_{e}=S-\left[\frac{V_{p}-V_{0}}{A}\right]^{1 / b} \\
R h o ; P_{p}=S-\sigma_{e}=S-\left[\frac{R h o-V_{0}}{A}\right]^{1 / b}
\end{array}\right\}
$$

For the wells where overpressure is caused by unloading mechanism, Bowers model 
for the unloading case (Equation (8)) was utilized to predict the pore pressure in the area.

$$
\begin{gathered}
V_{p} ; P_{p}=S-\left[\frac{V_{P}-V_{0}}{A}\right]^{u / b}\left(\sigma_{\max }\right)^{1-u} \\
\left(\sigma_{\max }\right)=\left[\frac{\left(V_{\max }-V_{0}\right)}{A}\right]^{1 / b}
\end{gathered}
$$

where $\sigma_{\max }$ is estimate of the effective stress at the onset of unloading, $V_{\max }$ is estimate of velocity at the onset of unloading, and $u$ is unloading parameter.

The velocity of unconsolidated fluid saturated sediments $\left(V_{0}\right)$ used for Niger Delta is $5000 \mathrm{ft} / \mathrm{s}=1524 \mathrm{~m} / \mathrm{s}$ (Ikon Science RokDoc). The constants $A$ and $b$ are the parameters calibrated with offset velocity versus effective stress data [12]. For Gulf of Mexico wells, $A$ varies from $10-20$ and $b$ varies from 0.7 - 0.75 [12]. In this work, the constants $A$ and $b$ was varied iteratively till a best fit with the pressure data was obtained (values are in Table 1).

\section{2) Eaton Model}

Eaton approach is a horizontal pressure method due to the fact that it compares in situ physical property to a normal compacted equivalent physical property at the same depth. It is valid as long as the normal compaction trend can be constructed for all depth of interest. Depending on the log type, Eaton's formula utilized is given as:

Using

$$
V_{p}: P_{p}=P_{o b s}-\left(P_{o b s}-P_{h y d}\right) \times\left(\frac{V_{i}}{V_{n}}\right)^{3}
$$

Using

$$
\text { Rho: } P_{p}=P_{o b s}-\left(P_{o b s}-P_{h y d}\right) \times\left(\frac{R h o}{R h o_{n}}\right)^{3}
$$

where $P_{p}$ is predicted (shale) pore pressure, $P_{o b s}$ is overburden pressure (rocks and fluid) below mud line, $P_{h y d}$ is hydrostatic pressure (fluid), $V_{n}$ is normal compacted shale velocity, and $V_{i}$ is interval velocity (for seismic data) or $V_{p}$ for well log data (Figure 3).

Table 1. Summarized empirical constants and parameters for all the wells.

\begin{tabular}{cccccc}
\hline Wells & $\begin{array}{c}\text { Eaton's } \\
\text { exponential parameter }\end{array}$ & $\begin{array}{c}\text { Bowers } \\
\text { parameter } A\end{array}$ & $\begin{array}{c}\text { Bowers } \\
\text { parameter } b\end{array}$ & $\begin{array}{c}\text { Unloading } \\
\text { onset depth (ft) }\end{array}$ & $\begin{array}{c}\text { Bowers } \\
\text { unloading parameter (U) }\end{array}$ \\
\hline $\mathrm{X}-1$ & 3.0 & 15.50 & 0.70 & $\cong 10,000$ & 5.5 \\
$\mathrm{X}-2$ & 3.0 & 15.00 & 0.75 & $\cong 13,000$ & 7.0 \\
$\mathrm{X}-3$ & 3.0 & 9.00 & 0.75 & $\cong 11,200$ & 5.5 \\
$\mathrm{Y}-1$ & 3.0 & 12.40 & 0.72 & Not applicable & Not applicable \\
$\mathrm{Y}-2$ & 3.0 & 12.2 & 0.71 & Not applicable & Not applicable \\
$\mathrm{Y}-3$ & 3.0 & 14.50 & 0.75 & Not applicable & Not applicable \\
\hline
\end{tabular}



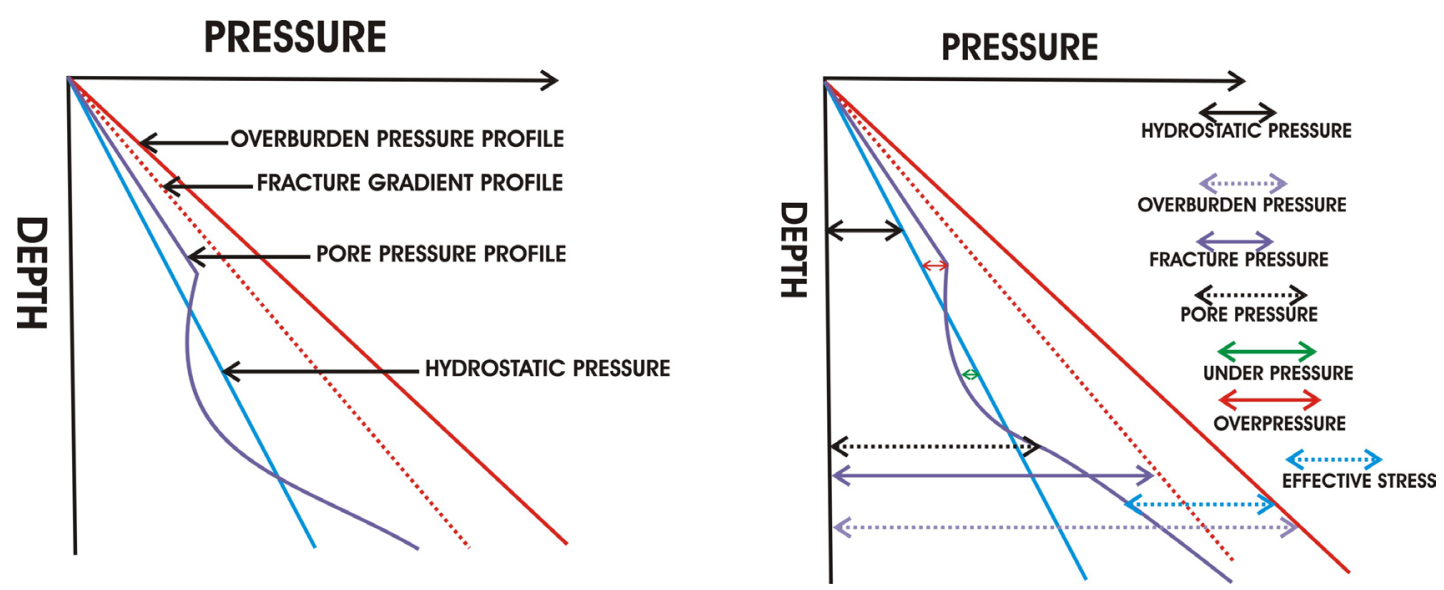

Figure 3. Schematic pressure-depth plot with illustration of typical terminologies used in pore pressure work [10].

\subsection{Fracture Gradient Prediction Models}

Two fracture gradient prediction models utilized in this study is the model proposed by [13] (Equation (12)) and the widely used Eaton's fracture gradient prediction model (Equation (13)).

[14] showed that fracturing will occur when:

$$
P_{f}=\frac{\left(S-P_{P}\right)}{3}+P_{p}
$$

where $P_{f}$ is Fracture pressure, $S$ is overburden pressure (Psi), $P_{P}$ is Pore pressure (Psi).

[15], gave fracture gradient prediction model as

$$
P_{f}=\frac{3 v}{2(1-v)}\left(\sigma_{v}-P_{p}\right)+P_{p}
$$

where $\sigma_{v}$ is vertical tension (vertical overburden stress) in psi, and $v$ is Poisson ratio given by Eaton as:

$$
v=\frac{\frac{1}{2}\left(\frac{V_{p}}{V_{s}}\right)^{2}-1}{\left(\frac{V_{p}}{V_{s}}\right)^{2}-1}
$$

\section{Results and Analysis}

\subsection{Overpressure Generating Mechanism}

The cross plot of $V_{p}$ and $R h o$ of the studied wells shows that the primary overpressure generating mechanism is the disequilibrium compaction of sediments (Figure 4 \& Figure 5). However, well X-1 shows evidence of other mechanisms other than disequilibrium compaction. These other overpressure generating mechanisms are clay diagenesis and fluid expansion (unloading). 


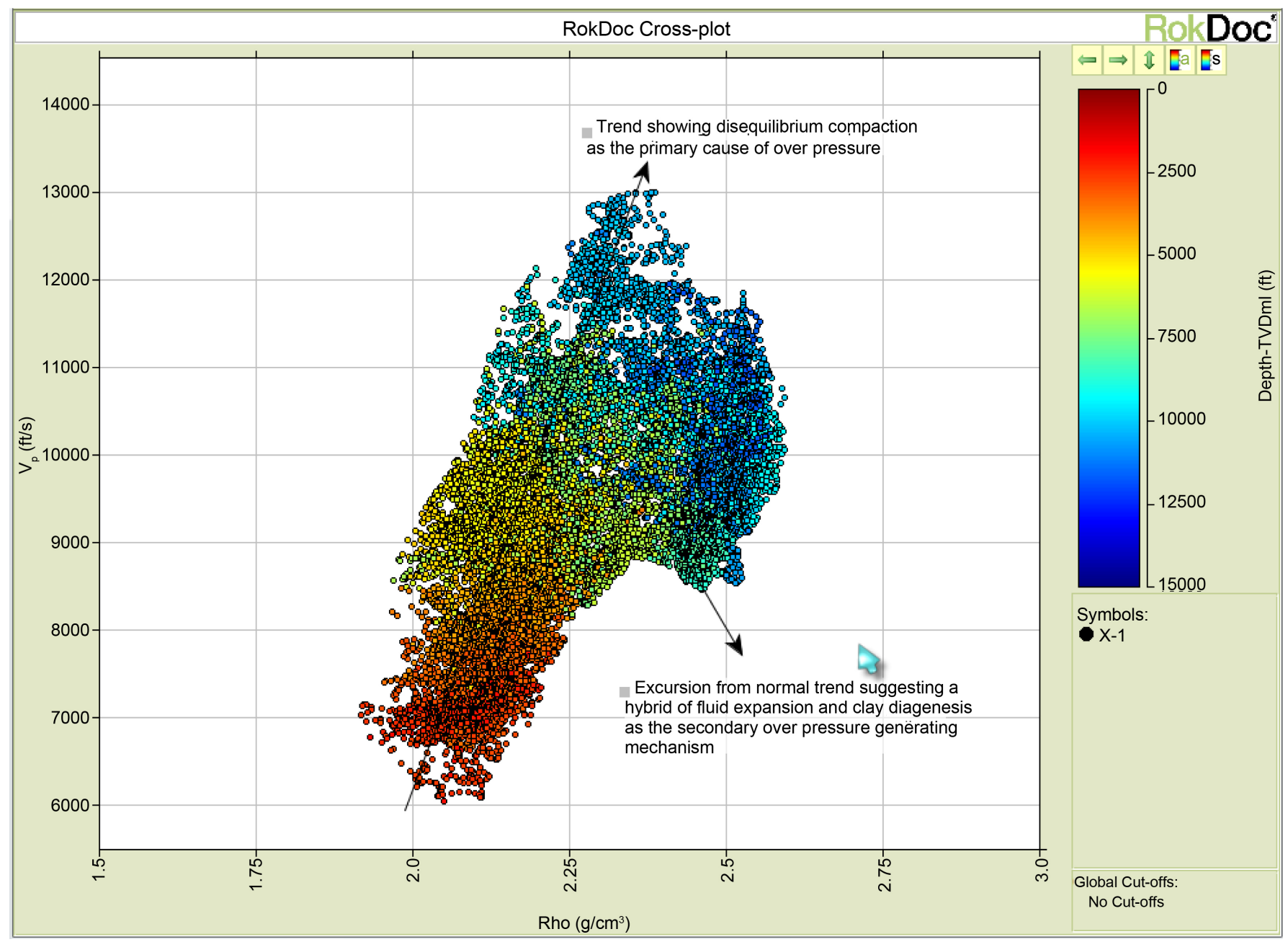

Figure 4. Cross plot of $V_{p}$ and $R h o$ for X-1 well coloured by true vertical depth (ft).

\subsection{Estimation of Pore Pressure by Different Methods}

Eaton's exponential and Bowers pore prediction models were the fundamental pore pressure prediction approaches employed in this work.

Eaton's exponential method predicts pore pressure quantitatively. The wells were calibrated with Eaton's exponential of 3 (same with Gulf of Mexico according to previous studies), utilizing Equations (10) and (11). There is significant difference between the prediction made from $V_{p}$ and that made from density log. Predictions from density log only coincide with measured pressure at shallow depth but did not show good similarity with the measured pressure at deeper depth. Eaton's exponential method falls short of accuracy in estimating the pressure beyond the depth at which the unloading starts. This is due to the fact that Eaton's approach is based on porosity anomaly and no associated porosity anomaly has been proven to be present in the unloading depths.

Two Bowers equations were utilized. Equation (7) was used in the case where disequilibrium compaction is the cause of over pressure while Equation (8) is applied to account for the unloading effect at the unloading onset depth. Bowers model for unloading 


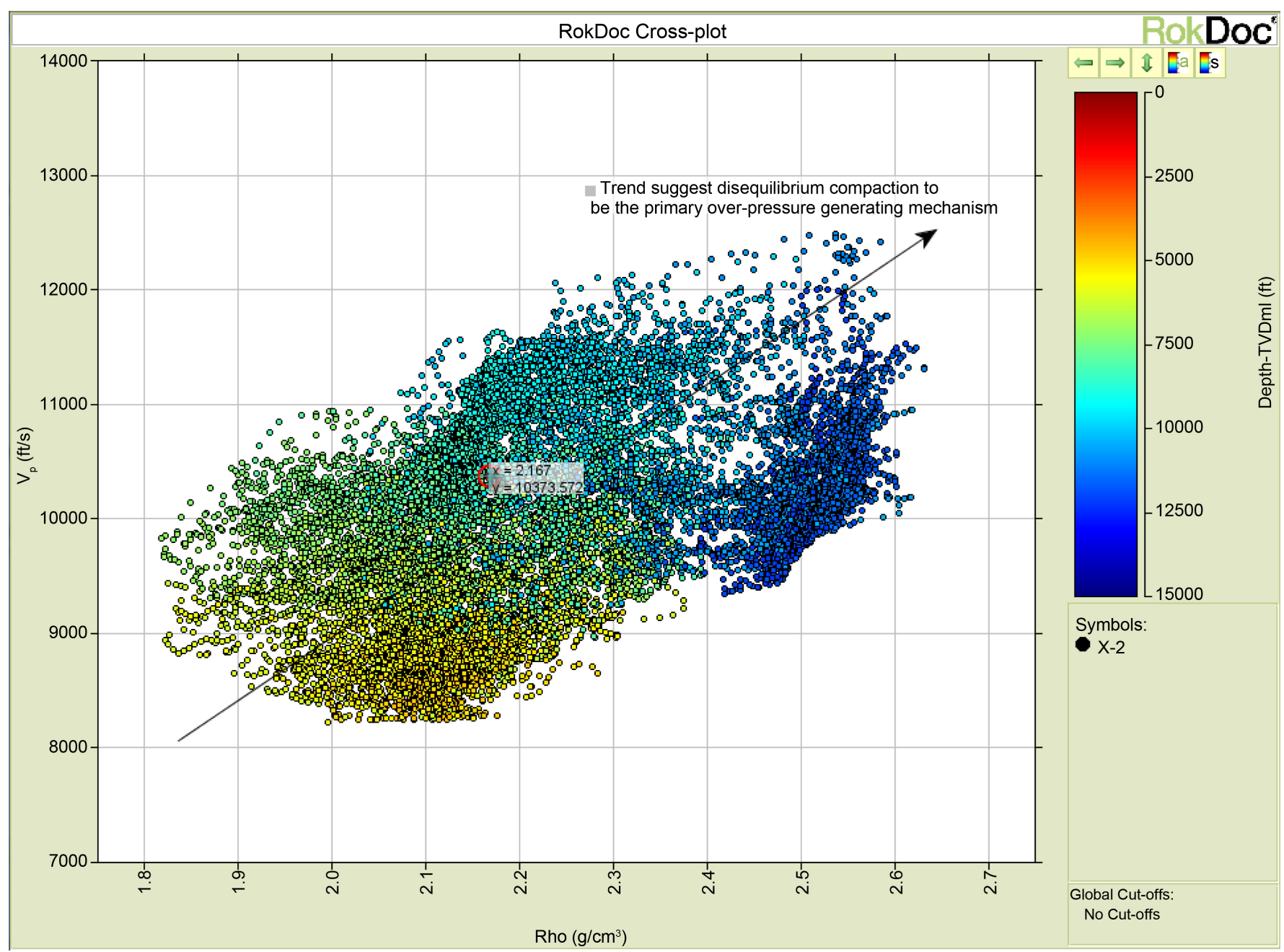

Figure 5. Cross plot of $V_{p}$ and Rho for X-2 well coloured by true vertical depth (ft).

case was applied in well X-1 that has evidence of unloading at depth of approximately $10,000 \mathrm{ft}$. A single trend was established that joined the two Bowers models (disequilibrium compaction and unloading cases) at depth of 10,080 with the upper portion being trend from disequilibrium compaction model and the lower portion being trend from unloading model. The Bowers parameters that gave reasonable pore pressure trend that shows close match with the measured pressure are: $A=15.50, b=0.70, U=$ 5.5. The two models gave appreciable results with relatively different, but closely related constants for each Well (Table 1). Prediction with Rho log was not successful. The sample of pressure trend for X-1 is displayed in Figure 6.

\subsection{Estimation of Fracture Pressure by Different Methods}

The integrated Bowers pressure trend of disequilibrium compaction and unloading was chosen to be the reference pressure trend for the fracture pressure prediction. This is due to the fact that the trend integrates the curves from unloading case and for the case of disequilibrium compaction. 


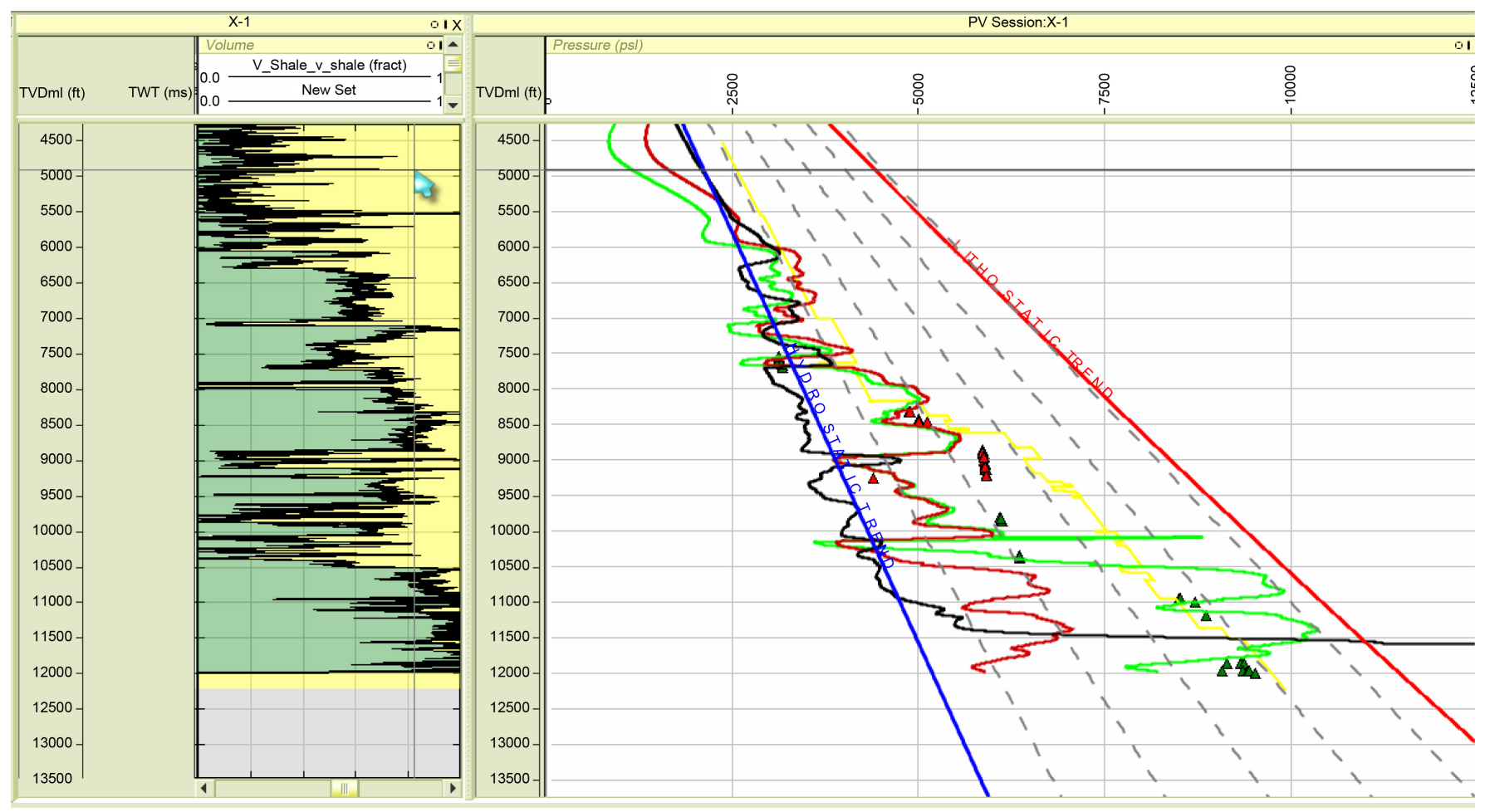

Figure 6. Pressure profile for X-1. The first column shows the shale lithologies (green portion) and sand (yellow portion). In the second column the yellow trend is mud weight gradient, black trend is Eaton's pressure trend from Rho log, red trend is Eaton's pressure trend from $V_{p} \log$, green trend is integrated bower's pressure trend from $V_{p} \log$.

Thus for the fracture pressure prediction made using Equations (12) and (13), $P_{p}$ is the pore pressure result predicted using Equations (7) and (8), $S$ is the overburden stress calculated with Equation (2) is the Poisson ratio (Equation (14)).

Hubert/Willis fracture model (Equation (12)) and Eaton's fracture gradient models (Equation (13)) matched very well at different depth intervals mostly at shallower depths and where the poisson's value is not given owing to quality of $V_{p}$ and $V_{s} \log$ data. At intervals where Poisson's ratio exists, Eaton's fracture model value increases more than that of Hubbert and Willis model prediction. This change can be attributed to the incorporation of the stress ratio of the rock which the Hubbert and Willis model does not consider.

By observation of the well logs and drilling record, pore pressure increases with increase in Poisson's ratio but the reverse is the case when there is connection gas in the formation. This observation is subject to further investigation. Thus when further investigations confirm these findings, Poisson's ratio could be used as pore pressure indicator. Sample of the fracture pressure predicted for X-1 is shown in Figure 7 while the pressure profile of Well X-1 is given in Table 2.

\section{Discussion of Results}

The two major methods of pore pressure prediction in this study (Eaton's and Bower's models) show very similar results when predicted with $V_{p}$ data. As can be seen from 


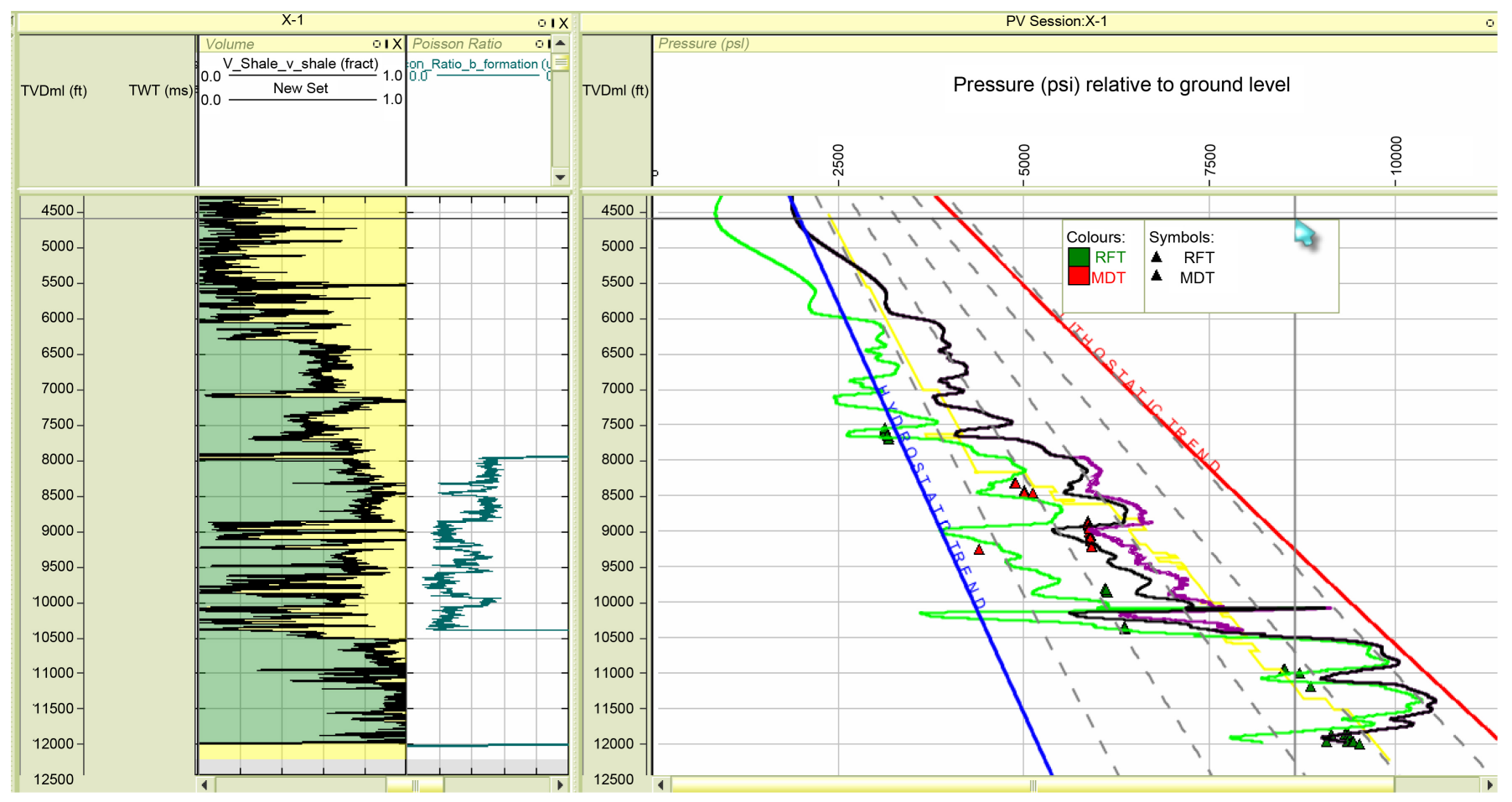

Figure 7. Fracture pressure profile for X-1. The first column shows the shale lithologies (green portion) and sand (yellow portion). The second column is the calculated poisson ratio. In the third column, green trend is the integrated Bower's pore pressure trend, purple trend is the Eaton's fracture pressure trend while black trend is the fracture pressure trend from Hubbert and Willis model.

Figure 6, the pore pressure predictions with density log is greatly hampered and incoherent with measured formation pressure; this could be due to the fact that other factors like hydrocarbon saturation and porosity affect the density log. Bowers model gave a null pressure value with density log. The predicted pore pressure with Eaton's pressure model using Rho and $V_{p}$ logs under predicts pore pressure at deeper depths where unloading is present. Bowers model significantly gave reasonable match with the formation's measured pressure (from RFT and MDT). This ability of the Bowers' model to predict pore pressure at unloading depths is an edge to the Eaton's model. The Niger Delta wells have shown evidence of secondary overpressure generating mechanism, hence the Bower's model using $V_{p} \log$ was chosen as the most reliable pore pressure prediction model and it was also used for the fracture pressure prediction.

Due to variations in the starting points of the log data, the average initial overpressure onset could not be guaranteed but the onset of overpressure varies widely between $6000.00 \mathrm{ft}$ true vertical depth (TVD) to $11,017.10 \mathrm{ft}$ (TVD) for wells X-1 and X-2 respectively. The highest recorded pressure was observed in well X-2 with pressure value of 11,017.10 Psi (Figure 8) at depth of 11,007.10 ft (TVD). The highest over pressured zones as observed from the studied Wells lie approximately between 6000 and 11,017.1 $\mathrm{ft}$ (TVD).

The predicted pore pressure shows reasonable match with the measured pressure data for the wells especially in the shale lithology intervals. Since this study is shale based, prediction in sand is not reliable. Also the predicted pore pressure in this work 
Table 2. Pressure values of well X-1.

\begin{tabular}{|c|c|c|c|c|c|c|c|}
\hline \multirow{2}{*}{ Measured Depth (Ft) } & \multirow{2}{*}{$\begin{array}{c}\text { Predicted } \\
\text { Pore Pressure (Psi) } \\
\text { From } V_{P} \text { using } \\
\text { Eaton's Model }\end{array}$} & \multirow{2}{*}{$\begin{array}{c}\text { Predicted } \\
\text { Pore Pressure (Psi) } \\
\text { From Rho using } \\
\text { Eaton's Model }\end{array}$} & \multirow{2}{*}{$\begin{array}{c}\text { Predicted } \\
\text { Pore Pressure (Psi } \\
\text { From } V_{p} \text { using } \\
\text { Bowers' Model }\end{array}$} & \multicolumn{2}{|c|}{ P-Hyd P-Lithos } & \multirow{2}{*}{$\begin{array}{c}\text { Predicted } \\
\text { Fracture } \\
\text { Pressure (Psi) using } \\
\text { Eaton's Model }\end{array}$} & \multirow{2}{*}{$\begin{array}{l}\text { Predicted Fracture } \\
\text { Pressure (Psi) } \\
\text { using Hubbert } \\
\text { \& Willis Model }\end{array}$} \\
\hline & & & & (Psi) & (Psi) & & \\
\hline 6000 & 2568.4 & 2834.7 & 2130.8 & 2598.0 & 5233.0 & 3165.1 & 3164.9 \\
\hline 6250 & 3332.3 & 3141.6 & 3031.3 & 2706.2 & 2418.6 & 3843.1 & 3842.9 \\
\hline 6500 & 3388.5 & 2617.0 & 3055.4 & 2814.5 & 5703.6 & 3938.3 & 3938.2 \\
\hline 6750 & 3393.7 & 2740.7 & 3039.1 & 2922.8 & 2863.4 & 4011.9 & 4011.7 \\
\hline 7000 & 3500.2 & 3401.6 & 3148.8 & 3031.1 & 6204.7 & 4167.6 & 4167.4 \\
\hline 7250 & 3273.3 & 3298.6 & 2890.6 & 3139.2 & 3324.4 & 4077.3 & 4077.2 \\
\hline 7500 & 3615.9 & 3038.7 & 3282.4 & 3247.5 & 6707.0 & 4424.1 & 4423.9 \\
\hline 7750 & 3368.5 & 3758.9 & 3037.8 & 3355.8 & 3799.4 & 4343.2 & 4343.0 \\
\hline 8000 & 4517.3 & 3027.3 & 4295.7 & 3464.0 & 7205.6 & 5265.8 & 5265.6 \\
\hline 8250 & 5036.5 & 3339.7 & 4896.3 & 3572.2 & 4281.4 & 5924.0 & 5754.7 \\
\hline 8500 & 4824.5 & 3519.8 & 4667.3 & 3680.5 & 7733.7 & 5910.5 & 5689.4 \\
\hline 8750 & 5268.3 & 3507.0 & 5172.0 & 3788.7 & 4767.2 & 6319.4 & 6114.1 \\
\hline 9000 & 5500.1 & 3489.9 & 5445.4 & 3897.0 & 8264.8 & 6609.5 & 6385.2 \\
\hline 9250 & 4085.8 & 4472.4 & 4088.9 & 4005.3 & 5265.3 & 6103.8 & 5562.2 \\
\hline 9500 & 4856.2 & 3585.7 & 4868.3 & 4113.5 & 8763.6 & 6493.7 & 6166.8 \\
\hline 9750 & 5125.9 & 3847.1 & 5197.5 & 4221.7 & 5765.6 & 6770.7 & 6476.6 \\
\hline 10,000 & 5098.3 & 4122.2 & 5242.6 & 4330.0 & 9290.5 & 7064 & 6591.9 \\
\hline 10,250 & 6025.4 & 3998.7 & 6174.1 & 4438.3 & 6290.1 & 7570.1 & 7301.2 \\
\hline 10,500 & 4527.8 & 4215.8 & 5882.6 & 4546.5 & 9811.5 & 7648.7 & 7192.3 \\
\hline 10,750 & 6117.0 & 4497.6 & 9225.4 & 4654.7 & 6808.5 & 9509.1 & 9509.1 \\
\hline 11,000 & 6701.2 & 4557.5 & 9847.5 & 4763.0 & $10,348.2$ & $10,014.0$ & $10,014.4$ \\
\hline 11,250 & 5658.4 & 5218.8 & 8337.9 & 4871.3 & 7338.6 & 9097.8 & 9097.8 \\
\hline 11,500 & 6948.5 & 5510.0 & $10,242.8$ & 4979.5 & $10,877.7$ & $10,455.0$ & $10,454.5$ \\
\hline 11,750 & 6744.1 & $11,113.6$ & $10,080.6$ & 5087.7 & 7863.2 & $10,435.0$ & $10,435.2$ \\
\hline 12,000 & 6124.1 & $1.01 \mathrm{E}+10$ & 8922.7 & 5195.9 & $11,417.2$ & 9754.4 & 9754.3 \\
\hline
\end{tabular}

falls within pressure range with some predictions by previous studies in Niger Delta. The summarised values from this study are given in Table 3.

Eaton's model and Hubbert and Willis model were the two fracture pressure models used. The predictions of the fracture pressure in this work showed significant reason as why the Eaton's fracture pressure model is considered the most accurate. One of such reasons is that the Eaton's fracture pressure incorporates the stress ratio of the rock (Poisson's ratio) which the Hubbert and Willis model does not consider. As can be seen 

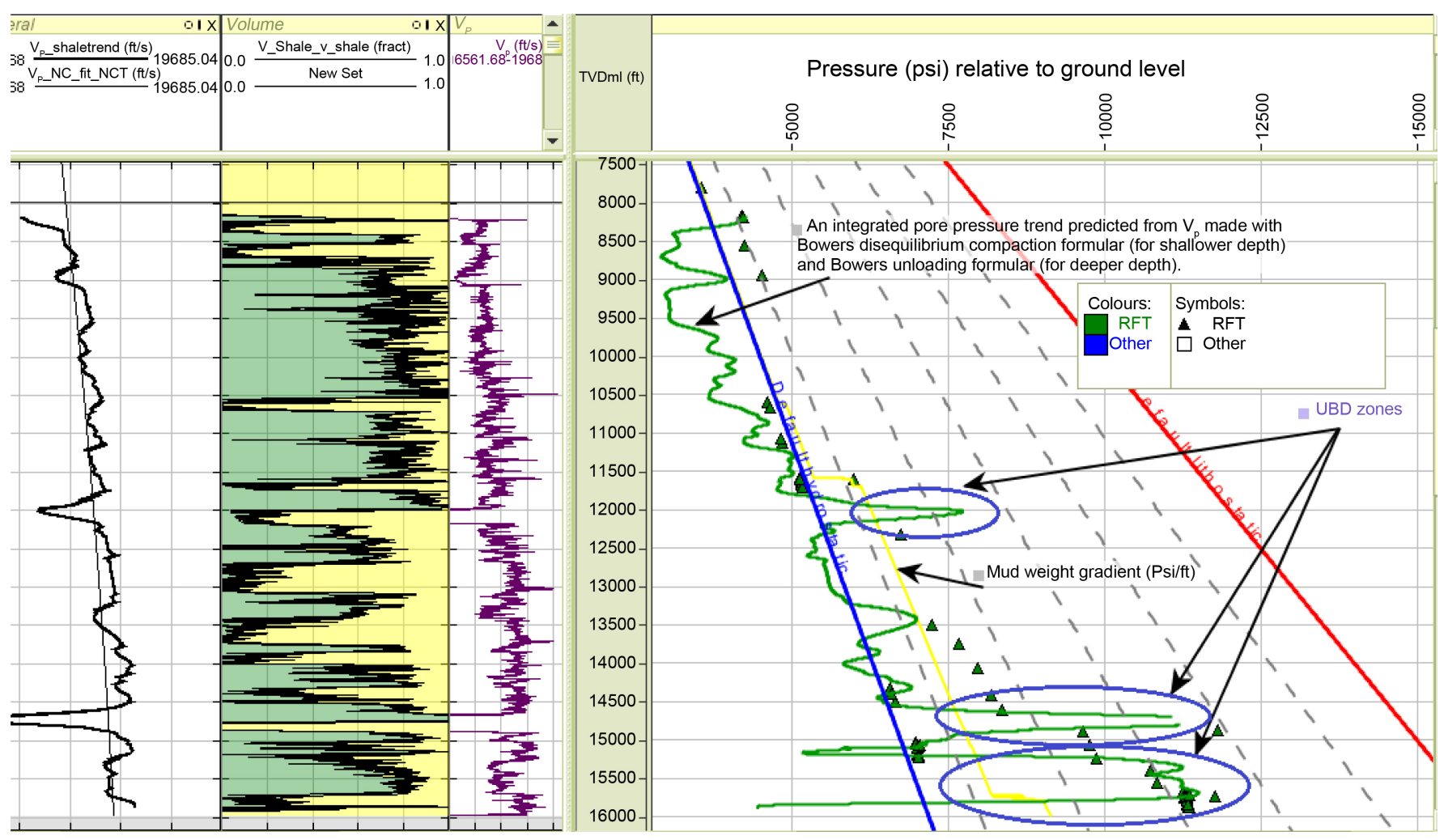

Figure 8. Integrated Bowers pressure trend for X-2 well, joined at depth of 13,000 ft.

Table 3. Summarised pressure values (from Bowers' model) indicating observed onset of overpressure and maximum observed pressure.

\begin{tabular}{ccccc}
\hline \multirow{2}{*}{ WELLS } & \multicolumn{2}{c}{ OVERPRESSURE ONSET } & \multicolumn{2}{c}{ MAXIMUM OBSERVED PRESSURE } \\
\cline { 2 - 5 } & TVD (FT) & Pressure value (Psi) & TVD (FT) & Pressure value (Psi) \\
\hline X-1 & 6000.00 & 2130.87 & $11,388.8$ & $10,388.60$ \\
X-2 & 8180.61 & 711.70 & $15,751.00$ & $11,536.04$ \\
X-3 & 7009.80 & 3156.70 & $14,925.70$ & $10,970.23$ \\
Y-1 & 7800.00 & 3017.39 & $16,303.00$ & 9321.50 \\
Y-2 & $11,017.10$ & 5297.29 & $12,208.00$ & $11,017.10$ \\
Y-3 & 7044.67 & 3181.95 & $10,914.90$ & 9779.99 \\
\hline
\end{tabular}

from Figure 7, the two models; Eaton's model and Hubbert and Willis model gave a matching prediction up till the depth where the Poisson's ratio was calculated (column 2 of Figure 9). The mismatch of these two models is influenced by the incoporation of the stress ratio (Poisson ratio) calculated for the well. As can be observed from Figure 9, the predicted fracture pressure with Eaton's model is significantly higher than that obtained with Hubbert and Willis model at depths where the Poison ratio was calculated and used.

The highest pressure zones at a depth range of 10,000 to 16,000 ft (TVD) obtained in this study corroborates that of [16] who used modified Eaton's approach in their study 

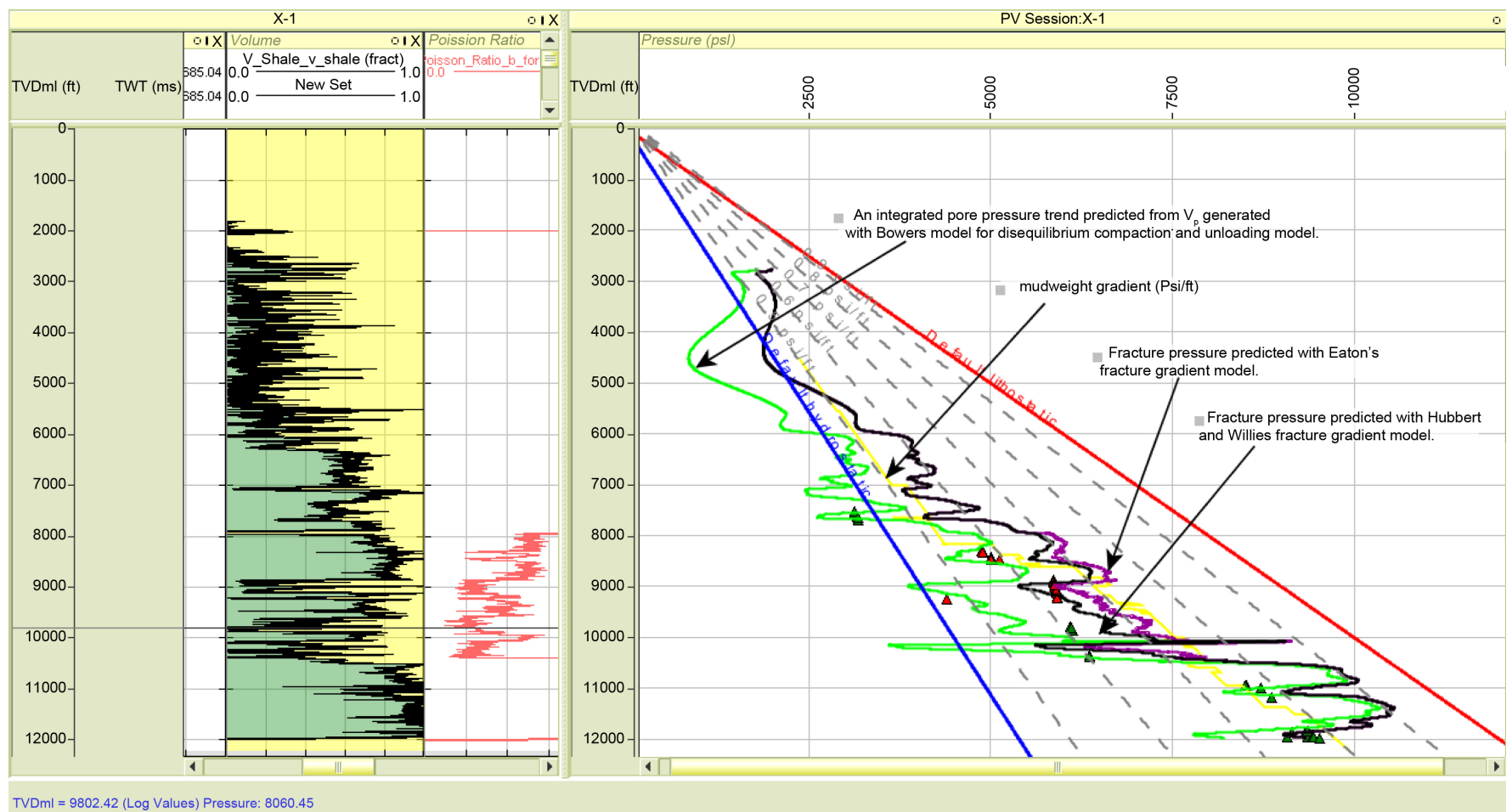

TVDml = 9802.42 (Log Values) Pressure: 8060.45

Figure 9. Fracture pressure for well X-1. Purple trend is done with Eaton's model while black trend is done with Hubbert and Willis model.

on Quantitative evidence of secondary mechanisms of overpressure generation in Parts of Onshore Niger Delta. They observed that overpressure is prominent from 12,371.42 $\mathrm{ft}(3771.77 \mathrm{~m})$ and continued to total depth. Also, [17] using Eaton's D-exponent model to predict overpressure in a Field in Niger Delta concluded that majority of overpressure situation in the area occurs between the depth of $8000 \mathrm{ft}$ and 13,000 ft. These values are relatively higher than the average top of overpressure range of 6000 to $11,017 \mathrm{ft}$ (TVD) obtained in this study.

[18] in their estimation of overpressure using Eaton's method in Onshore Niger Delta from wire line data observed the onset of overpressure below the depth of $8000 \mathrm{ft}$; a value that the lowest overpressure onset obtained for this study fell into. [19] predicted overpressure regime from seismic data in Niger Delta and established the abnormal formation pressure gradient in the over pressured section to be $21.7 \mathrm{kpa} / \mathrm{m}$ at a depth of $2643 \mathrm{~m}$. Over pressure gradient value range of 0.8 to $0.9 \mathrm{psi} / \mathrm{ft}$ was calculated in this work.

[20] utilizing lithology logs and detailed information from seismic traces observed tops of overpressure zones ranging from $1608.8 \mathrm{~m}$ to $3001.4 \mathrm{~m}$. These zones were characterized by high water saturation ( $52 \%$ to $80.2 \%$ ) and low porosity (16.55\% to $30.8 \%$ ). The results of their top overpressure zones is however, lower than that obtained in this study. [8] also predicted pore pressure in parts of Niger Delta from seismic data, and employing Bower's technique of velocity-to-pore pressure transform, obtained the top of overpressure as $3500 \mathrm{~m}$ within the shale region of Agbada Formation. This value falls within the range of 6000 to 11,017 observed in this work. The results of other workers 
[21], [22] in the study area confirmed the presense of overpressure.

\section{Conclusion}

This study has been able to investigate the cause of the overpressure in the Niger Delta sedimentary basin. The major overpressure generation mechanism in the Niger Delta is disequilibrium compaction of sediments. Other secondary mechanisms were also observed in some wells at greater depths. The secondary overpressure mechanism shows hybrid of clay diagenesis and fluid expansion as the causative mechanism. On the average, the secondary overpressure mechanisms start at depth (TVD) of about 10,000 ft (Table 3). The zones associated with secondary overpressure mechanism have very low effective stress with significant high pore pressure. From the quality of the predictions made with $V_{p}$ and Rho in comparison with the pressure data, it can be concluded that $V_{p}$ is more ideal in prediction of overpressure in the Niger Delta and in the case where the cause of the overpressure is unknown, and the two Bowers methods are recommended. This is due to the fact that Eaton's approach under-predicts pore pressure in formations where there is evidence of secondary overpressure generating mechanism.

\section{Acknowledgements}

The Authors are grateful to SPDC Port Harcourt for providing the petrophysical data used in this study. We extend our appreciation to Ikon Science/Geopressure Technology for the RokDoc software support.

\section{References}

[1] Schlumberger Ltd. (2014). http://www.glossary.oilfield.slb.com

[2] Opara, I.A. and Onuoha, M.K. (2009) Pre-Drill Pore Pressure Prediction from 3-D Seismic Data in Parts of the Onshore Niger Delta Basin. Proceedings of the Nigeria Annual International Conference and Exhibition (NAICE09), Nigeria, 3-5 August 2009. http://dx.doi.org/10.2118/128354-ms

[3] O'Connor, S., Richard, S., Jammal, H. and Richard, L. (2011) Deep Pore Pressure Prediction in Challenging Areas, Malay Basin, South East Asia. Proceedings, Indonesia Petroleum Association, 35 ${ }^{\text {th }}$ Annual Convention and Exhibition, May 2011, 1-17.

[4] Nweke, I.F. (2013) Analytical Model to Predict Pore Pressure in Planning High Pressure, High Temperature Wells in Niger Delta. International Journal of Engineering and Science, 2, 53-63.

[5] Bourgoyne Jr., A.T. and Rocha Jr., A.L. (1996) Simple Way to Estimate Fracture Pressure Gradient. Shell Petroleum Development Company, 153-159.

[6] Hoesni, M.J. (2004) The Origin of Overpressure in the Malay Basin and Its Influence on Petroleum System. Ph.D Thesis, University of Durham, Durham.

[7] Kogbe, C.A. (1989) Geology of Nigeria. 2nd Edition, Rock View Ltd., Jos, Nigeria.

[8] Emujakporue, G.O. (2013) Pore Pressure Prediction from Seismic Data in Part of the Onshore Niger Delta Sedimentary Basin. Physics International, 4, 152-159. http://dx.doi.org/10.3844/pisp.2013.152.159

[9] Evamy, D.D., Haremboure, P., Karmmerling, W.A. and Molloy, F.A. (1978) Hydrocarbon Habitat of Tertiary Niger Delta. AAGP Bulletin, 62, 1-39. 
[10] Goodwyne, O.K. (2012) Pressure Prediction and Underbalance Drilling in the Deepwater Niger Delta. Msc Thesis, Durham University, United Kingdom.

[11] Bowers, G.L. (1995) Pore Pressure Estimation from Velocity Data; Accounting for Overpressure Mechanism besides Undercompaction. SPE Drilling \& Completion, 10, 89-95. http://dx.doi.org/10.2118/27488-PA

[12] Zhang, J. (2011) Pore Pressure Prediction from Well Logs: Methods, Modifications and New Approaches. Shell Exploration and Production Company, Houston, Texas.

[13] Hubbert, M.K. and Willis, D.G. (1957) Mechanics of Hydraulic Fracturing. Transactions of Society of Petroleum Engineers of AIME, 210, 153-163.

[14] Hughes, B. (1996) Formation Pressure Evaluation Reference Guide. Baker Hughes Inteq Training and Development, Houston.

[15] Eaton, B.A. (1972) The Effect of Overburden Stress on Geopressure Prediction from Well Logs. Journal of Petroleum Technology, 24, 929-934. http://dx.doi.org/10.2118/3719-PA

[16] Nwozor, K.K., Omudu, M.L., Ozumba, B.M., Egbuachor, C.J., Onwuemesi, A.G. and Anike, O.L. (2013) Quantitative Evidence of Secondary Mechanisms of Overpressure Generation: Insights from Parts of Onshore Niger Delta, Nigeria. Petroleum Technology Development Journal, 3, 64-88.

[17] Ugwu, S.A. and Nwankwo, C.N. (2014) Integrated Approach to Geopressure Detection in the X-Field, Onshore Niger Delta. Journal of Petroleum Exploration and Production Technology, 4, 215-231. http://dx.doi.org/10.1007/s13202-013-0088-4

[18] Udo, K., Akpan, M. and Agbasi, O. (2013) Estimation of Overpressures in Onshore Niger Delta Using Well Logs. International Journal of Science and Research, 4, 2780-2784.

[19] Osinowo, O.O., Oladunjoye, M.A. and Olayinka, A.I. (2015) Overpressure Prediction from Seismic Data and Implications on Drilling Safety in the Niger Delta, Southern Nigeria. Petroleum Technology Development Journal, 5, 13-26.

[20] Alao, O., Ofuyah, W. and Abegunrin, A. (2014) Detecting and Predicting over Pressure Zones in the Niger Delta Nigeria: A Case Study of Afam Field. Journal of Environment and Earth Science, 4, 13-20.

[21] Uko, E.D., Emudianughe, J.E. and Tamunobereton-ari, I. (2013) Overpressure Prediction in the North-West Niger Delta, Using Porosity Data. Journal of Applied Geology and Geophysics, 1, 42-50. http://dx.doi.org/10.9790/0990-0134250

[22] Owalabi, O.O., Okpobiri, G.A. and Obomanu, I.A. (1990) Prediction of Abnormal Pressure in the Niger Delta Using Well Logs. Proceedings of the CIM/SPE International Technical Meeting (ITMP0), Calgary, 10-13 June 1990. http://dx.doi.org/10.2118/21575-ms 
Submit or recommend next manuscript to SCIRP and we will provide best service for you:

Accepting pre-submission inquiries through Email, Facebook, LinkedIn, Twitter, etc.

A wide selection of journals (inclusive of 9 subjects, more than 200 journals)

Providing 24-hour high-quality service

User-friendly online submission system

Fair and swift peer-review system

Efficient typesetting and proofreading procedure

Display of the result of downloads and visits, as well as the number of cited articles

Maximum dissemination of your research work

Submit your manuscript at: http://papersubmission.scirp.org/

Or contact ojg@scirp.org 